Ahmed, R., R., Streimikiene, D., \& Zheng, X. (2021). The Impact of Proactive Environmental Strategy on Competitive and Sustainable Development of Organizations. Journal of Competitiveness, 13(4), 5-24. https://doi.org/10.7441/joc.2021.04.01

\title{
The Impact of Proactive Environmental Strategy on Competitive and Sustainable Development of Organizations
}

\author{
- Rižwan Raheem Ahmed, Dalia Streimikiene, Xiaosong Zheng
}

\begin{abstract}
The purpose of this research is to evaluate the impact of proactive environmental strategy, competitive differentiation advantage \& cost-leadership competitive advantage for the competitive, sustainable development of an organization in terms of its performances, for instance, product strategy, production, process \& financial performances. We incorporated technological eco-innovation as a mediating factor \& corporate image as a moderator between exogenous \& endogenous variables. We have collected 798 responses from China, India, Pakistan, Bangladesh, United Arab Emirates, and Vietnam. For the data analyses, we employed a structural equation modeling-based multivariate approach and conditional process modeling. The novelty and significance of the undertaken study rested in multifaceted outcomes; for instance, the proactive environmental strategy, the competitive advantage of differentiation \& competitive advantage of cost leadership have a significant \& positive impact on the sustainable development of an organization in terms of its performances, for example, product strategic, production \& financial performances. The findings further demonstrate that technological eco-innovation as a mediating factor \& corporate image as a moderating factor played vital and significant influencers between exogenous and endogenous variables. Finally, the TodaYamamoto causality showed the two-ways directionality between exogenous \& endogenous variables. The outcomes have provided critical practical and societal implications for the industry and society. The companies may incorporate the environment as a cornerstone in short \& longterm strategies for sustainable development. On the other hand, organizations may provide an eco-friendly environment to society.
\end{abstract}

Keywords: csustainable development, proactive environmental strategy, competitive advantage of differentiation, cost-leadership competitive advantage, strategic performance, financial performance

JEL Classification: C12, M14, Q2

Received: December, 2020

1st Revision: June, 2021

Accepted: July, 2021

\section{INTRODUCTION}

The bursting of environmental hazards, for instance, climate change, smog \& natural resource depletion, have become a global concern. Thus, sustainable development and green growth are matters of great interest to organizations. According to Fousteris et al. (2018) and Olson (2008), the 
firms have intense pressure to carry out their social responsibility to improve the environmental climate. Additionally, several stakeholders, such as regulatory bodies, international environmental protection agencies, government, non-governmental organizations, and communities, also influence to minimize environmental hazards (Pan et al., 2020; Gupta \& Barua, 2018; Katsikeas et al., 2016). Sarcastically, very few studies have discussed the influence of proactive environmental strategy and their impact on sustainable development (Do \& Nguyen, 2020; Biçakcıoglu, 2018). The competitive advantages are essential, and very few empirical studies have been carried out to assimilate several kinds of competitive advantages by incorporating proactive environmental strategies to attain sustainable growth (Kuo et al., 2021; Ko \& Liu, 2017; Fousteris et al., 2018). According to Lee \& Rhee (2007) and Murillo-Luna et al. (2011), the firms have implemented general ecological strategies. Still, the association is unclear between firms' competitive advantages and proactive environmental strategies (Do et al., 2019). However, clarifying this link between proactive environmental strategy and sustainable development advocates that the firms implement these environmental strategies for a long-run competitive advantage (Do \& Nguyen, 2020; Bae, 2017). According to Jiang et al. (2018), this association of companies' performance and proactive environmental strategies explores several processes of organizational performances. Kuo et al. (2021), Junquera \& Barba-Sánchez (2018), and Leonidou et al. (2017) have examined companies' performance adopting proactive environmental strategies using indicators of financial performance and other researchers using indicators of environmental performance (Bae, 2017). However, several researchers believe that the firms' performance is not only based on environmental \& financial performances but also the operational performance indicators (Liu \& Shu, 2020), and indicators of marketing performance (Leonidou et al., 2017). Despite several measures taken to examine the influence of proactive environmental strategies on companies' performance, still, it is not clear which measure is more appropriate; hence, organizational performance is a multidimensional \& multifaceted phenomenon that is essentially challenging for measuring precise indicators (Do et al., 2019; Leonidou et al., 2017). Thus, the undertaken study incorporated numerous performances based on previous literature (Kaletnik \& Lutkovska, 2020; Junquera \& Barba-Sánchez, 2018).

According to Kliestik et al. (2018), organizations have both economic and moral responsibilities to their stakeholders, including shareholders, customers, government, and the general community. The enterprises are not only responsible for enhancing their profitability, but at the same time, they should also follow the legal and ethical requirements of society. Similarly, the organizations should take care of the environment and provide a pollution-free ecosystem, which provides a competitive advantage to the organization. In the long run, environmental strategies increase organizational product innovation, production, processes, operations, and financial performances. It is interesting that the previous literature regarding the importance of proactive environmental strategies has been restricted to a distinctive perspective. For example, Mishra \& Yadav (2021), Lu et al. (2020), Liu \& Shu (2020), Leonidou et al. (2017), and Fousteris et al. (2018) emphasized SMEs. However, other studies demonstrated the effect of environmental strategies on a single industry (Omri, 2020; Junquera \& Barba-Sánchez, 2018; Barba-Sanchez \& Atienza-Sahuqillo, 2016). Thus, there is a strong need to address the impact of proactive environmental strategies on both services \& manufacturing sectors with diverse performances such as product, process, production, strategic and financial performance. 
Additionally, previous studies have been carried out on the developed world, especially western economies (Mishra \& Yadav, 2021; Liu \& Shu, 2020). Thus, there was a dire need to address the impact of proactive environmental strategies on developing economies. Hence, the study focused on the services \& manufacturing sectors of China, India, Pakistan, UAE, Bangladesh, and Vietnam. Moreover, there was a strong need to address the impact of proactive environmental strategies on emerging economies (Do \& Nguyen, 2020; Lu et al., 2020). Hence, this research has identified this gap, developed a modified model with resource-based theory, and taken the constituents of proactive environmental strategies such as the competitive advantage of differentiation \& competitive advantage of cost leadership. This research evaluates the impact of proactive environmental strategy and its two components on the product, process, production, strategic, and financial performances. Moreover, we employed technological eco-innovation as a mediating variable and corporate image as a moderating factor in the adapted conceptual model. We examined the effects of mediation \& moderation between independent and dependent factors. The undertaken study focuses on the developing \& emerging economies like China, India, UAE, Vietnam, Pakistan \& Bangladesh from the perspective of manufacturing \& services sectors. Thus, this research addresses these issues and discusses how proactive environmental strategies are beneficial to the emerging and developing economies for a green environment.

\section{THEORETICAL BACKGROUND AND HYPOTHESES DEVELOPMENT}

\subsection{Theory underpinning - Resourced-based view theory}

Previous researchers have employed stakeholders' theory, institutional theory \& resource-based view theory to carry out their studies regarding environmental strategies (Liu \& Shu, 2020). The stakeholder theory focuses on the different stakeholders of an organization, including employees, customers, community, regulatory bodies, environmental activists, and shareholders, how they affect the organizational decisions regarding the environmental strategies (Valaskova et al., 2020). However, first-time Hart \& Dowell (2007) used a resource-based view theory that explained the environmental strategy, components, and concerns. According to Hart \& Dowell (2007), the resource-based view theory phenomenon focuses on internal elements that benefit companies in attaining sustainable competitive advantage. The resource-based view theory is the most employed theory that better explains the association between proactive environmental strategies and companies' financial performance and competitive advantages (Henriques \& Sadorsky, 1999). According to Peter et al. (2020), industry 4.0 enhances significant variations to enhance their manufacturing plants, increasing production, processes, products, and financial performances. Industry 4.0 increases their value propositions, which are also integrated with systems, supply chain, suppliers, and buyers. This strategy shows that any organization adopting any specific approach, including a proactive environmental strategy, can also enhance its product innovation, production, strategy, processes, and financial performance.

\subsection{Categorizations of environmental strategies}

Companies have numerous strategic possibilities to reduce business strategies' adverse impacts on the natural environment (Liu \& Shu, 2020). Adopting a proactive environmental strategy allows 
companies to fulfill corporate social responsibility besides attaining competitive advantage and financial performance (Bıçakcıoglu, 2018). According to Lee \& Rhee (2007), every organization has a different option to implement environmental strategies according to the size, width, nature, and depth of the environmental issues. According to Henriques \& Sadorsky (1999), the companies' environmental strategies are divided into proactive, reactive, accommodative, and defensive strategies. According to Do \& Nguyen (2020) and Banerjee et al. (2003), regardless of several categorizations of environmental strategies from the reactive stage to the proactive level, focus on the commitment of environmental concerns. However, the reactionary strategies are typically obligatory, and the organization has to meet them. The proactive environmental strategies are least implemented in developing economies' industries that can potentially affect competitive advantage and sustainable development for services \& manufacturing sectors (Mishra \& Yadav, 2021; Do et al., 2019).

\subsection{Proactive environmental strategies (PES) and competitive advantages}

According to Bıçakcıoglu (2018), the competitive advantage is an organizational ability to generate more economic value than its minor competitors by creating more significant meshes paybacks using grander differentiation and lesser costs. Pan et al. (2020) and Fousteris et al. (2018) have suggested that proactive environmental strategies can attain both differentiation \& low-cost leadership competitive advantages. According to Do \& Nguyen (2020) and Hart \& Dowell (2011), sustainable growth \& competitive advantage can be achieved by controlling pollution \& effective use of a firm's resources using resource-based view theory. The competitive differentiation advantage comprises a unique corporate image, innovation, better customer value \& higher productivity (Do \& Nguyen, 2020). The proactive green environmental strategies promote an organizational unique corporate image than its competitors (Leonidou et al., 2017). According to Liu \& Shu (2020) and Biçakcıoglu (2018), significant improvement in organizational resources \& abilities due to proactive environmental strategies bring more environmentally friendly products that enhance the competitive advantage as well. Thus, we have framed the following hypotheses:

H1: PES has a positive \& significant association with the CDA.

H2: PES has a positive \& significant association with the CCA.

\subsection{Competitive advantage \& firms' performance}

Previous literature has demonstrated an affirmative association between corporate performance and competitive advantage. This research examined the influence of competitive differentiation advantage (CDA) \& cost-leadership competitive advantage (CCA) derived from the proactive environmental strategies (PES) on strategic performance, product, process, production, and financial performances. High reliability, high quality, product flexibility, value-added features, and better customer support are distinctive features of product performance (Kuo et al., 2021). However, the strategic performance indicators display managers' non-economic \& economic goals, such as long-term growth, customer satisfaction, enhancing impacts on the natural environment, and market share increase. The process performance belongs to the services sectors that provide swift and flawless services to the customers. However, production is related to the manufacturing industry, including the manufacturing process, product system, and market cycle time (Valaskova et al., 2020). The competitive advantages create a corporate image, increase customer value through 
innovative products \& services, and enhance corporate social responsibility in the community (Do \& Nguyen, 2020). According to Leonidou et al. (2017) and Biçakcioglu (2018), proactive environmental strategies, cost-leadership \& differentiation competitive advantages increase the corporate image and organizational performance. According to Omri (2020), the eco-friendly characteristics of products \& services increase the differentiation \& cost leadership competitive advantages through higher product \& service reliability, higher quality, added advantage of product $\&$ service, and better customer support, which enhances the product \& service performance. Thus, better environmental \& sustainable development increases the strategic performance of a firm. Moreover, eco-friendly services \& products drive advances in production design \& processes and operational systems that improve production improvement indicators (Peters et al., 2020; Do \& Nguyen, 2020). Lastly, higher repeat purchases, more revenue generation, and more significant market share increase the financial performance of proactive environmental strategies (PES), costleadership, and competitive differentiation advantage (Kaletnik \& Lutkovska, 2020; Banerjee et al., 2003; Fousteris et al., 2018). Thus, we have framed the following hypotheses.

H3: PES has a significant and positive impact on the product, strategy, process, production, and financial performances.

H4: CDA has a significant and positive impact on the product, strategy, process, production, and financial performances.

H5: CCA has a significant and positive impact on the product, strategy, process, production, and financial performances.

\subsection{Technological eco-innovation (TEI)}

According to Kaletnik \& Lutkovska (2020) and Barboza (2019), several kinds of technological ecoinnovation, such as product $\&$ process innovations, market success, eco-innovation development, and organizational innovation. Technological eco-innovation has a significant role in bringing a sustainable environment through ecological progress (Tullani et al., 2018; Becker \& Egger, 2013). According to Omri (2020) and Chang (2016), technological eco-innovation is also known as the environment innovation that comprises of creation of products, processes, which leads to environmental development. The technological eco-innovation is implementing the design, which permits an organization to mitigate, observe, prevent, and diagnose environmental concerns (Chang, 2016). Technological eco-innovation specifies the development \& creation of ideas, processes \& products, and operating procedures, decreasing environmental hazards \& attains environmental sustainability (Lee, 2020; Cheng et al., 2014). Previous literature such as Lu et al. (2020) and Tullani et al. (2018) have demonstrated that technological innovation is a vital mediating variable between proactive environmental strategies (PES), competitive differentiation advantage (CDA) \& cost-leadership competitive advantage (CCA), and organizational performance (product, process, production, strategic \& financial). Thus, we framed the following hypotheses:

H6A: TEI significantly \& positively mediates between PES and product, process, strategy, production, \& financial performances.

H6B: TEI significantly \& positively mediates between CDA and product, process, strategy, production, \& financial performances.

H6C: TEI significantly \& positively mediates between CCA and product, process, strategy, production, \& financial performances. 


\subsection{Corporate image $(\mathrm{Cl})$}

Proactive environmental strategies enhance the progressive corporate image. The strong corporate image, mission, vision, core values, culture, and strategies should be combined with the corporate business's proactive environmental strategies (Han et al., 2019). The corporate image is defined as "a positive perception of a firm in the mind of a customer due to positive organizational strategies towards the well-being of environment \& community" (Fousteris et al., 2018). The positive image also enhances organizational services \& products in customers' minds that create longterm sustainable development \& competitive advantage. The corporate image is also determined through distinct features of a brand, service, belief system, brand perception, name, design, and logo (Kuo et al., 2021; Lu et al., 2020). The corporate image translates into the company's brand image that reflects the intangible values, which also validates the brand value and interrelates with the long-run competitive advantage $\&$ sustainable growth of a firm. The proactive environmental strategies, differentiation \& cost-leadership competitive advantages increase the corporate image and long-term sustainable development. The corporate image is an unseen asset \& resource of the firm that could not be copied. Several research studies such as Han \& Kim (2019) and Lu et al. (2020) demonstrated that the moderator (corporate image) is an influential factor between proactive environmental strategies, competitive differentiation advantage (CDA) \& cost-leadership competitive advantage (CCA), and organizational performances (product, process, production, strategic \& financial). Thus, the following hypotheses are framed:

H7A: Corporate image significantly moderates between PES and product, process, strategy, production, \& financial performances.

H7B: Corporate image significantly moderates between CDA and product, process, strategy, production, \& financial performances.

H7C: Corporate image significantly moderates between CCA and product, process, strategy, production, \& financial performances.

\section{RESEARCH OBJECTIVE, METHODOLOGY, AND DATA}

\subsection{Objective of the research}

The objective of this research is to evaluate the impact of proactive environmental strategy and its two components, such as constituents, the competitive advantage of differentiation \& the competitive advantage of cost leadership on the product, process, production, strategic, and financial performances. Additionally, we employed technological eco-innovation as a mediating variable and corporate image as a moderating factor in the adapted conceptual model. We examined the effects of mediation \& moderation between independent and dependent factors. The undertaken study focuses on the developing \& emerging economies like China, India, UAE, Vietnam, Pakistan, and Bangladesh.

\subsection{Research design and measurement scales}

The undertaken research is quantitative \& cross-sectional; we used an adapted questionnaire $\&$ conceptual framework. The measurement scales of the adapted questionnaire are based on previous literature. We have selected modified items of all the considered factors from previous literature and authenticated them through exploratory factor analysis for the research study. We 
have taken four dependent variables, and each dependent variable carries three items. However, we consider three independent factors, and each construct has three items. Additionally, we considered one mediating variable, i.e. technological eco-innovation, with three items, and one moderating variable such as corporate image with three items. Thus, we have added ten constructs and thirty items of these constructs in our questionnaire in Annexure-II. However, Annexure I contains demographic questions in which we asked gender, marital status, age, education, experience, and income, so we have six questions in the demographic section.

\subsection{Sampling strategy and data collection method}

For the data collection, we have used purposive and quota-sampling techniques to better represent different geographic regions according to their industrial population size. We collected 798 responses in total. However, we have floated 1,000 questionnaires. Thus in this way, the response rate was $79.80 \%$. We collected 257 responses from personal emails, which were taken from LinkedIn and companies' websites. 361 responses were taken from LinkedIn social media and 180 responses were taken in person via face-to-face interviews. We have collected 367 responses from the services sectors and 431 responses from the manufacturing sectors. We have collected 195 responses from the senior managers of the Chinese services \& manufacturing industry, 149 responses from India, and 133 responses from Pakistan. However, 111 responses were collected from the services \& manufacturing sectors of Bangladesh, 109 answers from the United Arab Emeritus (UAE), and 101 responses were taken from the services \& manufacturing sectors of Vietnam.

\subsection{Estimation methods for data analysis}

For the data analysis, we have employed several estimation techniques such as descriptive analyses to establish the collected data's normality pattern. We used exploratory factor analysis to validate the measurement scales \& constructs. For this purpose, we utilized Bartlett's Sphericity \& KMO methods. Moreover, total variance was employed to substantiate the constructs \& items and appropriateness of the data sample. We used CFA and fit-indices to validate the measurement model \& structural model for our considered modified conceptual framework. To evaluate the direct \& indirect hypothesized relationship, we employed conditional process modeling in which we measured the direct association between independent variables such as proactive environmental strategies, differentiation \& cost-leadership competitive advantages, and different measures of organizational performance such as product performance, process performance, strategy performance, production performance, and financial performance. Finally, we employed the Toda-Yamamoto causality method to examine the directionality and cause \& effect between the variables.

\section{RESULTS AND DISCUSSION}

\subsection{Descriptive analyses}

The fundamental features of constructs, for instance, kurtosis, skewness \& standard deviation, are measured through descriptive statistics. The data normality is a pre-condition for employing the parametric statistical procedures; therefore, we had converted our data into a $\mathrm{Z}$ score and 
measured the descriptive analysis. The findings demonstrated that the readings of kurtosis are higher than \pm 3 , and readings of standard deviation \& skewness are greater than \pm 1.5 (Ahmed et al., 2020). Thus, it is substantiated that our data follows the normality patterns, and now we can employ SEM-based multivariate modeling.

\subsection{Reliabilities and validities}

We extracted the average variance extracted, composite reliabilities \& factor loadings values from the rotated component matrix through exploratory factor analysis. The findings of Table 1 exhibited that readings of all the factor loadings of items are vacillating between $0.85-0.95$. The items are the questions, which explain the constructs. Therefore, items are known as the observed variables. Hence, it proved the condition for discriminant validities of items (Ahmed et al., 2020; Hair et al., 2017). Additionally, the average variance measurements are higher than 0.50; thus, it has also fulfilled the requirement of convergent validities of items (Lu et al., 2020). Finally, the readings of the Cronbach's entire alpha are more significant than 0.60; thus, it showed the consistency \& reliability of the collected data (Byrne, 2009).

Tab. 1 - Reliabilities \& validities. Source: own research

\begin{tabular}{|c|c|c|c|c|c|}
\hline Factors & Items & FL & CA & CR & AVE \\
\hline \multirow{3}{*}{ Proactive Environmental Strategy } & PES1 & .905 & \multirow{3}{*}{.905} & \multirow{3}{*}{.931} & \multirow{3}{*}{.819} \\
\hline & PES2 & .886 & & & \\
\hline & PES3 & .924 & & & \\
\hline \multirow{3}{*}{ Competitive Differentiation Advantage } & CDA1 & .905 & \multirow{3}{*}{.902} & \multirow{3}{*}{.930} & \multirow{3}{*}{.818} \\
\hline & CDA2 & .886 & & & \\
\hline & CDA3 & .922 & & & \\
\hline \multirow{3}{*}{ Cost-Leadership Competitive Advantage } & CCA1 & .927 & \multirow{3}{*}{.925} & \multirow{3}{*}{.947} & \multirow{3}{*}{.856} \\
\hline & CCA2 & .901 & & & \\
\hline & CCA3 & .948 & & & \\
\hline \multirow{3}{*}{ Product Performance } & PP1 & .935 & \multirow{3}{*}{.917} & \multirow{3}{*}{.941} & \multirow{3}{*}{.842} \\
\hline & PP2 & .882 & & & \\
\hline & PP3 & .935 & & & \\
\hline \multirow{3}{*}{ Process Performance } & PSP1 & .903 & \multirow{3}{*}{.898} & \multirow{3}{*}{.926} & \multirow{3}{*}{.808} \\
\hline & PSP2 & .871 & & & \\
\hline & PSP3 & .922 & & & \\
\hline \multirow{3}{*}{ Strategic Performance } & SP1 & .915 & \multirow{3}{*}{.904} & \multirow{3}{*}{.931} & \multirow{3}{*}{.819} \\
\hline & $\mathrm{SP} 2$ & .870 & & & \\
\hline & SP3 & .929 & & & \\
\hline \multirow{3}{*}{ Production Performance } & PRP1 & .929 & \multirow{3}{*}{.927} & \multirow{3}{*}{.948} & \multirow{3}{*}{.860} \\
\hline & PRP2 & .905 & & & \\
\hline & PRP3 & .949 & & & \\
\hline
\end{tabular}




\begin{tabular}{|c|c|c|c|c|c|}
\hline \multirow{3}{*}{ Financial Performance } & FP1 & .923 & \multirow{3}{*}{.902} & \multirow{3}{*}{.929} & \multirow{3}{*}{.813} \\
\hline & FP2 & .899 & & & \\
\hline & FP3 & .884 & & & \\
\hline \multirow{3}{*}{ Technological Eco-innovation } & TEI1 & .917 & \multirow{3}{*}{.896} & \multirow{3}{*}{.924} & \multirow{3}{*}{.803} \\
\hline & TEI2 & .892 & & & \\
\hline & TEI3 & .879 & & & \\
\hline \multirow{3}{*}{ Corporate Image } & CI1 & .932 & \multirow{3}{*}{.924} & \multirow{3}{*}{.946} & \multirow{3}{*}{.854} \\
\hline & $\mathrm{CI} 2$ & .912 & & & \\
\hline & $\mathrm{CI} 3$ & .929 & & & \\
\hline
\end{tabular}

Note: PES=Proactive environmental strategy; $\mathrm{CDA}=$ Competitive differentiation advantage; CCA $=$ Cost leadership competitive advantage; $\mathrm{PP}=$ Product performance; $\mathrm{PSP}=$ Process performance; $\mathrm{SP}=\mathrm{Strategic}$ performance; $\mathrm{PRP}=$ Production performance; $\mathrm{FP}=$ Financial performance; $\mathrm{TEI}=$ Technological eco-innovation; $\mathrm{CI}=$ Corporate image; Note $1,2,3$...etc. shows the number of items.

\subsection{Exploratory factor analysis - EFA}

The undertaken study's conceptual model comprises modified items and constructs; therefore, exploratory factor analysis is the right choice to examine the fitness of altered items and constructs (Byrne, 2009). We have constructed a modified conceptual model and examined the authenticity through EFA. The EFA reduces the redundant items and constructs and condenses them into possible items \& constructs (Ahmed et al., 2020). The considered modified hypothesized model consisted of three independent variables (proactive environment strategy, differentiation \& costleadership advantages) with three items each. Additionally, there was one mediator, technological eco-innovation with three items, one moderator, i.e., corporate images with three items, and outcome variables have three items each, for instance, product, process, strategy, production, and financial performances. The outcomes of Table 2 exhibited that the hypothesized measurement model is considered to be appropriate because the factor loadings of every item oscillate from 0.85 to 0.95 (Emory \& Cooper, 1991).

\subsection{Kaiser-Meyer-Olkin, Bartlett's \& total variance explained analyses}

The suitability and robustness of the data are measured through the Kaiser-Meyer-Olkin (KMO) method. The calculated KMO reading is 0.733 , which is considered a good deal against the threshold value of 0.50 (Kaiser, 1974). Similarly, the readings of Bartlett's Sphericity $(\mathrm{p}=0.000)$ test exhibited the appropriateness of sampling against the standard value of $p<0.05$. We also measured the total variance explained the value that showed the total cumulative variance (84.83\%), which is excellent value vis-à-vis 50\% (Ahmed et al., 2019). Additionally, the eigenvalues of every construct are more than one. Thus, both cumulative variance \& eigenvalues confirmed the fitness of all the items and constructs.

\subsection{Confirmatory factor analysis - CFA}

The CFA is a procedure to evaluate the constructs and items, which were previously employed in research studies; the CFA confirms whether those items \& constructs are also valid for the considered modified conceptual model of the undertaken research. Therefore, confirmatory 
factor analysis is the right choice to examine the fitness of previously used items and constructs (Byrne, 2009). We have constructed a hypothesized measurement model and examined the validity through CFA (Ahmed et al., 2020). The considered measurement model consisted of three independent variables (proactive environment strategy, differentiation \& cost-leadership advantages) with three items each. Additionally, there was one mediator, technological ecoinnovation with three items, one moderator, i.e., corporate images with three items, and outcome variables have three items each, for instance, product, process, strategy, production, and financial performances. The outcomes of different fit-indices, for instance GFI $=0.96, \mathrm{NFI}=0.94, \mathrm{IFI}=0.97$, TLI $=0.98$, CFI $=0.99$, RMSEA $=0.016$, RNI $=0.98$, PCFI $=0.84$, and PNFI $=0.85$ exhibited that the hypothesized measurement model is considered appropriate because readings of all the fitindices are within the prescribed range.

\subsection{Structural equation modeling - SEM}

The findings of different fit indices show that our hypothesized structural model is suitable as per the theory of structural equation modeling (Hair et al., 2017). In our considered hypothesized structural model, we have taken ten constructs with thirty-three items according to the SEM-based multivariate approach (Ahmed et al., 2020). The structural model comprises three independent variables (proactive environment strategy, differentiation \& cost-leadership advantages) with three items each. Additionally, one mediator technological eco-innovation with three items, one moderator, i.e., a corporate image with three items, and outcome variables such as product, process, strategy, production, and financial performances, have three items each. The detailed results of fit indices are within the prescribed limits, for instance GFI $=0.97, \mathrm{NFI}=0.93$, $\mathrm{IFI}=0.96, \mathrm{TLI}=0.97, \mathrm{CFI}=0.98, \mathrm{RMSEA}=0.041, \mathrm{RNI}=0.97, \mathrm{PCFI}=0.83$, and $\mathrm{PNFI}=0.82$; thus, our hypothesized structural model fits the undertaken study.

\subsection{Hypothesized direct relationship}

Table 2 exhibited the direct hypothesized association between independent \& dependent variables; we examined this relationship through standard regression weights (Ahmed et al., 2019). Table 2 suggested that proactive environmental strategy has a positive \& significant connotation with competitive differentiation advantage $\&$ cost-leadership competitive advantage. Findings further that independent variables, for instance, the proactive environmental strategy has a powerful \& affirmative association with the product, process, strategic, production, and financial performances. Similarly, independent variables, i.e., differentiation \& cost-leadership competitive advantages, also demonstrated a significant relationship with the product, process, strategy, production \& financial performances because $\mathrm{T}>2 \& \mathrm{p}<0.05$ all the cases. Thus, our proposed hypotheses $\mathrm{H} 1$ to $\mathrm{H} 5$ are supported. The results of this research are consistent with the previous studies, which demonstrated if the company's environmental business strategy is proactive, it may cause a competitive differentiation advantage. It also improves organizational performance in several ways, such as enhance financial performance, strategy performance, operational performance, product and innovative performance, etc. These performances create a positive image in existing customer minds, and retention of the customer will also be enhanced. Additionally, due to proactive environmental strategy, products' reliability and quality add more value to products, which attract prospective customers. Finally, cost leadership 
advantage also enhances the corporate image, employees' retention, strategic, financial, and operational performances of the organization (Mishra \& Yadav, 2021; Do et al., 2019; Kuo et al., 2021; Lu et al., 2020). However, the undertaken research is unique in the way that it used a modified multidimensional conceptual model that assesses the relationship between independent and dependent variables. Moreover, this research also examined the influence of mediation of technological eco-innovation and moderation of corporate image between independent \& dependent variables. Similarly, Kliestik et al. (2020), Ghisetti \& Rennings (2014), and González-Benito \& González-Benito (2006) concluded that the companies could manage and increase their profitability through proper reporting system strategies. The authors have explored the financial performance of organizations by taking different countries. The authors have taken Czech, Slovak, Hungarian, and Polish enterprises and analyzed and concluded that organizational financial performance is depended on the individual decisions of an organization. Thus, in this way, the undertaken study also demonstrated that every organization that follows proactive environmental strategies could increase its financial, process, strategy, operational, and product performances.

Tab. 2 - Postulated direct association. Source: own research

\begin{tabular}{|c|c|c|c|c|c|}
\hline & Independent Variables & $\begin{array}{l}\text { Regression } \\
\text { Paths }\end{array}$ & $\operatorname{SRW}(\beta)$ & SE & $\mathrm{T}$ \\
\hline H1 & $\begin{array}{l}\text { Proactive Environmental } \\
\text { Strategy }\end{array}$ & $\mathrm{PES} \rightarrow \mathrm{CDA}$ & 0.5450 & 0.030 & 17.61 \\
\hline $\mathrm{H} 2$ & $\begin{array}{l}\text { Proactive Environmental } \\
\text { Strategy }\end{array}$ & $\mathrm{PES} \rightarrow \mathrm{CCA}$ & 0.4266 & 0.030 & 14.14 \\
\hline \multirow{5}{*}{ H3 } & $\begin{array}{l}\text { Proactive Environmental } \\
\text { Strategy }\end{array}$ & $\mathrm{PES} \rightarrow \mathrm{PP}$ & 0.2427 & 0.309 & 7.86 \\
\hline & $\begin{array}{l}\text { Proactive Environmental } \\
\text { Strategy }\end{array}$ & $\mathrm{PES} \rightarrow \mathrm{PSP}$ & 0.1551 & 0.034 & 4.47 \\
\hline & $\begin{array}{l}\text { Proactive Environmental } \\
\text { Strategy }\end{array}$ & $\mathrm{PES} \rightarrow \mathrm{SP}$ & 0.4202 & 0.020 & 20.24 \\
\hline & $\begin{array}{l}\text { Proactive Environmental } \\
\text { Strategy }\end{array}$ & $\mathrm{PES} \rightarrow \mathrm{PRP}$ & 0.2406 & 0.025 & 9.30 \\
\hline & $\begin{array}{l}\text { Proactive Environmental } \\
\text { Strategy }\end{array}$ & $\mathrm{PES} \rightarrow \mathrm{FP}$ & 0.1618 & 0.027 & 6.15 \\
\hline \multirow{4}{*}{$\mathrm{H} 4$} & $\begin{array}{l}\text { Competitive Differentiation } \\
\text { Advantage }\end{array}$ & $\mathrm{CDA} \rightarrow \mathrm{PP}$ & 0.4389 & 0.022 & 19.21 \\
\hline & $\begin{array}{l}\text { Competitive Differentiation } \\
\text { Advantage }\end{array}$ & $\mathrm{CDA} \rightarrow \mathrm{PSP}$ & 0.6209 & 0.020 & 29.92 \\
\hline & $\begin{array}{l}\text { Competitive Differentiation } \\
\text { Advantage }\end{array}$ & $\mathrm{CDA} \rightarrow \mathrm{SP}$ & 0.9160 & 0.021 & 4.20 \\
\hline & $\begin{array}{l}\text { Competitive Differentiation } \\
\text { Advantage }\end{array}$ & $\mathrm{CDA} \rightarrow \mathrm{PRP}$ & 0.1353 & 0.023 & 5.87 \\
\hline
\end{tabular}




\begin{tabular}{|l|l|l|l|l|l|}
\hline H4 & $\begin{array}{l}\text { Competitive Differentiation } \\
\text { Advantage }\end{array}$ & $\mathrm{CDA} \rightarrow \mathrm{FP}$ & 0.3066 & 0.021 & 14.23 \\
\hline \multirow{3}{*}{$\mathrm{H} 5$} & $\begin{array}{l}\text { Cost-Leadership } \\
\text { Competitive Advantage }\end{array}$ & $\mathrm{CCA} \rightarrow \mathrm{PP}$ & 0.6072 & 0.033 & 18.24 \\
\cline { 2 - 7 } & $\begin{array}{l}\text { Cost-Leadership } \\
\text { Competitive Advantage }\end{array}$ & $\mathrm{CCA} \rightarrow \mathrm{PSP}$ & 0.7395 & 0.034 & 21.38 \\
\cline { 2 - 7 } & $\begin{array}{l}\text { Cost-Leadership } \\
\text { Competitive Advantage }\end{array}$ & $\mathrm{CCA} \rightarrow \mathrm{SP}$ & 0.4921 & 0.026 & 18.66 \\
\cline { 2 - 7 } & $\begin{array}{l}\text { Cost-Leadership } \\
\text { Competitive Advantage }\end{array}$ & $\mathrm{CCA} \rightarrow \mathrm{PRP}$ & 0.4171 & 0.030 & 13.76 \\
\cline { 2 - 6 } & $\begin{array}{l}\text { Cost-Leadership } \\
\text { Competitive Advantage }\end{array}$ & $\mathrm{CCA} \rightarrow \mathrm{FP}$ & 0.4290 & 0.031 & 13.80 \\
\hline
\end{tabular}

Note: SRW: Standard regression weights. H1-H5 decision: Supported, H1-H5 p = 0.000.

\subsection{Mediation analyses}

The findings of Table 3 demonstrated the mediation of technological eco-innovation between exogenous variables, for instance, proactive environmental strategy, differentiation \& cost-leadership competitive advantages, and endogenous variables, i.e., product, process, strategy, production, and financial performance. We examined mediation through the Bootstrapping method (Hayes \& Rockwood, 2020) and the Normal theory method. The zero does not occur between Boot LLCI \& Boot ULCI in all the cases in the Bootstrapping method. Thus, it is concluded that there is a perfect mediation of technological eco-innovation between exogenous \& endogenous variables. Similarly, in the Normal theory method, the readings of $\mathrm{Z}> \pm 1.96$ and $\mathrm{p}<0.05$ in all the cases, therefore, it is again established that the technological eco-innovation has a significant \& positive influence of mediator between independent $\&$ dependent variables. It is finally concluded that the hypotheses H6A to H6C are supported. The findings of this research are in line with the previous literature, which exhibited that eco-innovation environmental strategies bring more value addition in terms of new customers attraction and existing customers retention. The previous literature also demonstrated that technological eco-innovation provides long-term sustainable growth that further increases the market share, profitability of the firm, and share value of shareholders. The previous literature such as Kaletnik \& Lutkovska (2020), and Barboza (2019), Omri (2020), Mishra \& Yadav (2021), Do et al. (2019), and Chang (2016) also demonstrated that eco-innovation also creates differentiation advantage in terms of production, process, and product innovation. Nevertheless, this research is exclusive in the way that it used a modified multidimensional model not only to assess the direct impact between independent factors but also examined the mediation of technological eco-innovation between exogenous and endogenous variables.

Tab. 3 - Mediation analysis. Source: own research

\begin{tabular}{|l|l|l|l|l|l|l|l|l|}
\hline \multicolumn{2}{|l|}{ Mediation } & \multicolumn{3}{|l|}{ Bootstrapping Method } & \multicolumn{3}{l|}{ Normal Theory Method } \\
\cline { 3 - 10 } & $\begin{array}{l}\text { Indirect } \\
\text { Effect }\end{array}$ & $\begin{array}{l}\text { Boot } \\
\text { SE }\end{array}$ & $\begin{array}{l}\text { Boot } \\
\text { LLCI }\end{array}$ & $\begin{array}{l}\text { Boot } \\
\text { ULCI }\end{array}$ & $\begin{array}{l}\text { Indirect } \\
\text { Effect }\end{array}$ & S.E. & $Z^{*}$ \\
\hline H6A: & PES $\rightarrow$ TEI $\rightarrow$ PP & 0.4535 & 0.0259 & 0.4054 & 0.5075 & 0.4535 & 0.027 & 16.73 \\
\hline
\end{tabular}




\begin{tabular}{|l|l|l|l|l|l|l|l|l|}
\hline \multirow{3}{*}{ H6A } & $\mathrm{PES} \rightarrow \mathrm{TEI} \rightarrow \mathrm{PSP}$ & 0.4865 & 0.0312 & 04260 & 0.5466 & 0.4865 & 0.030 & 16.22 \\
\cline { 2 - 9 } & $\mathrm{PES} \rightarrow \mathrm{TEI} \rightarrow \mathrm{SP}$ & 0.4228 & 0.0272 & 0.3682 & 0.4752 & 0.4228 & 0.020 & 20.39 \\
\cline { 2 - 9 } & $\mathrm{PES} \rightarrow \mathrm{TEI} \rightarrow \mathrm{PRP}$ & 0.4298 & 0.0269 & 0.3780 & 0.4826 & 0.4298 & 0.023 & 18.13 \\
\cline { 2 - 9 } & $\mathrm{PES} \rightarrow \mathrm{TEI} \rightarrow \mathrm{FP}$ & 0.5605 & 0.0284 & 0.5051 & 0.6152 & 0.5605 & 0.027 & 20.47 \\
\hline \multirow{3}{*}{$\mathrm{H} 6 \mathrm{~B}:$} & $\mathrm{CDA} \rightarrow \mathrm{TEI} \rightarrow \mathrm{PP}$ & 0.3179 & 0.0208 & 0.2780 & 0.3592 & 0.3179 & 0.020 & 15.85 \\
\cline { 2 - 9 } & $\mathrm{CDA} \rightarrow \mathrm{TEI} \rightarrow \mathrm{PSP}$ & 0.2357 & 0.0247 & 0.1899 & 0.2863 & 0.2357 & 0.016 & 14.15 \\
\cline { 2 - 9 } & $\mathrm{CDA} \rightarrow \mathrm{TEI} \rightarrow \mathrm{SP}$ & 0.5066 & 0.0268 & 0.4522 & 0.5575 & 0.5066 & 0.026 & 19.31 \\
\cline { 2 - 9 } & $\mathrm{CDA} \rightarrow \mathrm{TEI} \rightarrow \mathrm{PRP}$ & 0.4159 & 0.0251 & 0.3692 & 0.4681 & 0.4159 & 0.023 & 17.80 \\
\cline { 2 - 9 } & $\mathrm{CDA} \rightarrow \mathrm{TEI} \rightarrow \mathrm{FP}$ & 0.4269 & 0.0264 & 0.3764 & 0.4781 & 0.4269 & 0.023 & 18.40 \\
\hline \multirow{3}{*}{$\mathrm{H} 6 \mathrm{C}:$} & $\mathrm{CCA} \rightarrow \mathrm{TEI} \rightarrow \mathrm{PP}$ & 0.2528 & 0.0226 & 0.2094 & 0.2979 & 0.2528 & 0.028 & 8.95 \\
\cline { 2 - 9 } & $\mathrm{CCA} \rightarrow \mathrm{TEI} \rightarrow \mathrm{PSP}$ & 0.1473 & 0.0276 & 0.0922 & 0.2016 & 0.1473 & 0.028 & 5.10 \\
\cline { 2 - 9 } & $\mathrm{CCA} \rightarrow \mathrm{TEI} \rightarrow \mathrm{SP}$ & 0.4035 & 0.0263 & 0.3538 & 0.4584 & 0.4035 & 0.023 & 16.89 \\
\cline { 2 - 9 } & $\mathrm{CCA} \rightarrow \mathrm{TEI} \rightarrow \mathrm{PRP}$ & 0.3545 & 0.0274 & 0.3000 & 0.4079 & 0.3545 & 0.026 & 13.38 \\
\cline { 2 - 8 } & $\mathrm{CCA} \rightarrow \mathrm{TEI} \rightarrow \mathrm{FP}$ & 0.4529 & 0.0310 & 0.3935 & 0.5174 & 0.4529 & 0.027 & 16.21 \\
\hline
\end{tabular}

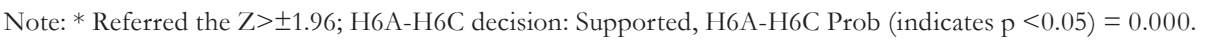

\subsection{Moderation analyses}

The findings of Table 4 demonstrated the effect of moderating variables between exogenous \& endogenous variables; results exhibited that corporate image has a significant moderating impact between exogenous variables, i.e., proactive environmental strategy, differentiation \& costleadership competitive advantages, and endogenous variables, for instance, product, process, strategic, production \& financial performance. According to Hayes \& Rockwood (2020), the readings, for example, $\mathrm{T}>2 \& \mathrm{p}<0.05$ for all the cases except the sub-hypotheses such as moderation of CI between PES and firm's strategic performance, moderation of CI between CDA and product \& process performances. However, the rest of the hypotheses \& sub-hypotheses of $\mathrm{H} 7 \mathrm{~A}$ to $\mathrm{H7C}$ are reinforced. The outcomes of this research are consistent with the previous literature, which demonstrated if the firm's environmental business strategy is proactive, it may cause a competitive differentiation advantage. It also improves the corporate image in the minds of existing and prospective customers. This leads to the customers' retention and customers' addition that increase firm's performance in several areas, for instance, financial performance, operational performance, strategic performance, product, and production performance, etc. Moreover, technological eco-innovation and proactive environmental strategies, also increase the corporate image that ultimately enhances the employees' retention, financial and operational performances of the organization (Han et al., 2019; Do \& Nguyen, 2020; Lu et al., 2020). However, the undertaken research is unique in the way that it used a modified conceptual multidimensional model that assesses simultaneously a direct impact between independent $\&$ dependent variables and moderation of corporate image between the exogenous and endogenous variables. 
Tab. 4 - Moderation analysis. Source: own research

\begin{tabular}{|c|c|c|c|c|c|c|c|c|}
\hline & Moderator & Moderation & Coefficient & SE & $\mathrm{T}$ & $\mathrm{P} *$ & LLCI & ULCI \\
\hline \multirow{10}{*}{ H7A: } & \multicolumn{8}{|c|}{ Moderating Effect of CI b/w PES and Firm's Product Performance (PP) } \\
\hline & CI & PES x CI & -0.1556 & 0.0152 & -10.21 & 0.0000 & -0.1855 & -0.1257 \\
\hline & \multicolumn{8}{|c|}{ Moderating Effect of CI b/w PES and Firm's Process Performance (PSP) } \\
\hline & CI & PES x CI & -0.2224 & 0.0152 & -14.59 & 0.0000 & -0.2523 & -0.1925 \\
\hline & \multicolumn{8}{|c|}{ Moderating Effect of CI b/w PES and Firm's Strategic Performance (SP) } \\
\hline & CI & PES x CI & -0.0131 & 0.0105 & -1.24 & 0.2132 & -0.0075 & 0.0337 \\
\hline & \multicolumn{8}{|c|}{ Moderating Effect of CI b/w PES and Firm's Production Performance (PRP) } \\
\hline & CI & PES x CI & -0.0738 & 0.0125 & -5.88 & 0.0000 & -0.0984 & -0.0491 \\
\hline & \multicolumn{8}{|c|}{ Moderating Effect of CI b/w PES and Firm's Financial Performance (FP) } \\
\hline & CI & PES x CI & -0.1140 & 0.0134 & -8.53 & 0.0000 & -0.1402 & -0.0878 \\
\hline \multirow{10}{*}{$\mathrm{H} 7 \mathrm{~B}$} & \multicolumn{8}{|c|}{ Moderating Effect of CI b/w CDA and Firm's Product Performance (PP) } \\
\hline & CI & CDA x CI & -0.0301 & 0.0155 & -1.94 & 0.0522 & -0.0604 & 0.0003 \\
\hline & \multicolumn{8}{|c|}{ Moderating Effect of CI b/w CDA and Firm's Process Performance (PSP) } \\
\hline & CI & CDA x CI & -0.0138 & 0.0134 & 1.02 & 0.3040 & -0.2126 & -0.0402 \\
\hline & \multicolumn{8}{|c|}{ Moderating Effect of CI b/w CDA and Firm's Strategic Performance (SP) } \\
\hline & CI & CDA x CI & -0.1003 & 0.0130 & -7.70 & 0.0000 & -0.1259 & -0.0747 \\
\hline & \multicolumn{8}{|c|}{ Moderating Effect of CI b/w CDA and Firm's Production Performance (PRP) } \\
\hline & CI & CDA x CI & -0.1033 & 0.0138 & -7.50 & 0.0000 & -0.1303 & -0.0763 \\
\hline & \multicolumn{8}{|c|}{ Moderating Effect of CI b/w CDA and Firm's Financial Performance (FP) } \\
\hline & CI & $\mathrm{CDA} \times \mathrm{CI}$ & -0.0376 & 0.0142 & -2.65 & 0.0081 & -0.0654 & -0.0098 \\
\hline \multirow{10}{*}{$\mathrm{H} 7 \mathrm{C}$} & \multicolumn{8}{|c|}{ Moderating Effect of CI b/w CCA and Firm's Product Performance (PP) } \\
\hline & CI & CCA x CI & -0.1774 & 0.0140 & -12.63 & 0.0000 & -0.2050 & -0.1499 \\
\hline & \multicolumn{8}{|c|}{ Moderating Effect of CI b/w CCA and Firm's Process Performance (PSP) } \\
\hline & CI & CCA x CI & -0.2114 & 0.0137 & -15.45 & 0.0000 & -0.2382 & -0.1845 \\
\hline & \multicolumn{8}{|c|}{ Moderating Effect of CI b/w CCA and Firm's Strategic Performance (SP) } \\
\hline & CI & CCA x CI & -0.0530 & 0.0120 & -4.41 & 0.0000 & -0.0766 & -0.0294 \\
\hline & \multicolumn{8}{|c|}{ Moderating Effect of CI b/w CCA and Firm's Production Performance (PRP) } \\
\hline & CI & CCA x CI & -0.1292 & 0.0125 & -10.36 & 0.0000 & -0.1537 & -0.1048 \\
\hline & \multicolumn{8}{|c|}{ Moderating Effect of CI b/w CCA and Firm's Financial Performance (FP) } \\
\hline & CI & CCA x CI & -0.1517 & 0.0131 & -11.55 & 0.0000 & -0.1775 & -0.1259 \\
\hline
\end{tabular}

Where ' $\mathrm{x}$ ' denoted for the multiplicative sign; * Indicates rejection of Null Hypotheses at $\mathrm{p}<0.05$; SE: Standard Error; LLCI: Lower Limit of Class Interval; ULCI: Upper Limit of Class Interval

\subsection{Toda-Yamamoto Causality analyses}

The Toda-Yamamoto causality suggested a two-way causation between proactive environmental strategy and competitive differentiation advantage \& cost-leadership competitive advantage. The detailed results are reported in Table 5. The outcomes of this research demonstrated that there is a two-way causation between the variables. Thus, they are interdependent. Therefore, proactive environmental strategy, cost leadership advantage, and competitive differentiation advantage 
have a causative positive influence on product, production, strategic, process, and financial performances or the other way around. However, previous literature does not employ cause and effect models. Thus, this research first time evaluated the cause and effect between the variables.

Tab. 5 - Causality analysis. Source: own research

\begin{tabular}{|c|c|c|c|c|}
\hline S. No. & Null Hypotheses & $\begin{array}{l}\text { Chi- } \\
\text { Square }\end{array}$ & P-Value & $\mathrm{GC}^{* *}$ \\
\hline 1 & $\begin{array}{l}\text { PES does not Granger cause on CDA } \\
\text { CDA does Granger cause on PES }\end{array}$ & $\begin{array}{l}7.7318 \\
6.2266\end{array}$ & $\begin{array}{l}0.0010^{* *} \\
0.0103 * *\end{array}$ & $\begin{array}{l}\text { YES } \\
\text { YES }\end{array}$ \\
\hline 2 & $\begin{array}{l}\text { PES does not Granger cause on CCA } \\
\text { CCA does Granger cause on PES }\end{array}$ & $\begin{array}{l}9.1874 \\
8.9319\end{array}$ & $\begin{array}{l}0.0000^{* *} \\
0.0000^{* *}\end{array}$ & $\begin{array}{l}\text { YES } \\
\text { YES }\end{array}$ \\
\hline 3 & $\begin{array}{l}\text { PES does not Granger cause on PP } \\
\text { PP does Granger cause on PES }\end{array}$ & $\begin{array}{l}6.234 \\
1.1599 \\
\end{array}$ & $\begin{array}{l}0.0301 * * \\
0.3469\end{array}$ & $\begin{array}{l}\text { YES } \\
\text { NO }\end{array}$ \\
\hline 4 & $\begin{array}{l}\text { PES does not Granger cause on PSP } \\
\text { PSP does Granger cause on PES }\end{array}$ & $\begin{array}{l}8.2298 \\
5.8327\end{array}$ & $\begin{array}{l}0.0020^{* *} \\
0.0572^{* *}\end{array}$ & $\begin{array}{l}\text { YES } \\
\text { YES }\end{array}$ \\
\hline 5 & $\begin{array}{l}\text { PES does not Granger cause on SP } \\
\text { SP does Granger cause on PES }\end{array}$ & $\begin{array}{l}5.899 \\
1.789\end{array}$ & $\begin{array}{l}0.0200^{* *} \\
0.4721\end{array}$ & $\begin{array}{l}\text { YES } \\
\mathrm{NO}\end{array}$ \\
\hline 6 & $\begin{array}{l}\text { PES does not Granger cause on PRP } \\
\text { PRP does Granger cause on PES }\end{array}$ & $\begin{array}{l}5.5240 \\
3.9234\end{array}$ & $\begin{array}{l}0.0118^{* *} \\
0.0731^{*}\end{array}$ & $\begin{array}{l}\text { YES } \\
\text { YES }\end{array}$ \\
\hline 7 & $\begin{array}{l}\text { PES does not Granger cause on FP } \\
\text { FP does Granger cause on PES }\end{array}$ & $\begin{array}{l}9.7589 \\
3.9012 \\
\end{array}$ & $\begin{array}{l}0.0000^{* *} \\
0.0842 *\end{array}$ & $\begin{array}{l}\text { YES } \\
\text { YES }\end{array}$ \\
\hline 8 & $\begin{array}{l}\text { CDA does not Granger cause on PP } \\
\text { PP does Granger cause on CDA }\end{array}$ & $\begin{array}{l}9.0844 \\
1.1765\end{array}$ & $\begin{array}{l}0.0000^{* *} \\
0.2210\end{array}$ & $\begin{array}{l}\text { YES } \\
\text { NO }\end{array}$ \\
\hline 9 & $\begin{array}{l}\text { CDA does not Granger cause on PSP } \\
\text { PSP does Granger cause on CDA }\end{array}$ & $\begin{array}{l}4.8832 \\
1.9201 \\
\end{array}$ & $\begin{array}{l}0.0800^{*} \\
0.4671\end{array}$ & $\begin{array}{l}\text { YES } \\
\mathrm{NO}\end{array}$ \\
\hline 10 & $\begin{array}{l}\text { CDA does not Granger cause on SP } \\
\text { SP does Granger cause on CDA }\end{array}$ & $\begin{array}{l}8.6802 \\
1.0219\end{array}$ & $\begin{array}{l}0.0000^{* *} \\
0.6789\end{array}$ & $\begin{array}{l}\text { YES } \\
\mathrm{NO}\end{array}$ \\
\hline 11 & $\begin{array}{l}\text { CDA does not Granger cause on PRP } \\
\text { PRP does Granger cause on CDA }\end{array}$ & $\begin{array}{l}7.1177 \\
1.0901\end{array}$ & $\begin{array}{l}0.0120^{* *} \\
0.8980\end{array}$ & $\begin{array}{l}\text { YES } \\
\mathrm{NO}\end{array}$ \\
\hline 12 & $\begin{array}{l}\text { CDA does not Granger cause on FP } \\
\text { FP does Granger cause on CDA }\end{array}$ & $\begin{array}{l}5.8421 \\
1.7998 \\
\end{array}$ & $\begin{array}{l}0.0201 * * \\
0.2923\end{array}$ & $\begin{array}{l}\text { YES } \\
\text { NO }\end{array}$ \\
\hline 13 & $\begin{array}{l}\text { CCA does not Granger cause on PP } \\
\text { PP does Granger cause on CCA }\end{array}$ & $\begin{array}{l}9.2310 \\
1.1785\end{array}$ & $\begin{array}{l}0.0000^{* *} \\
0.2765\end{array}$ & $\begin{array}{l}\text { YES } \\
\mathrm{NO}\end{array}$ \\
\hline 14 & $\begin{array}{l}\text { CCA does not Granger cause on PSP } \\
\text { PSP does Granger cause on CCA }\end{array}$ & $\begin{array}{l}7.8877 \\
1.1199\end{array}$ & $\begin{array}{l}0.0367^{* *} \\
0.2677\end{array}$ & $\begin{array}{l}\text { YES } \\
\mathrm{NO}\end{array}$ \\
\hline 15 & $\begin{array}{l}\text { CCA does not Granger cause on SP } \\
\text { SP does Granger cause on CCA }\end{array}$ & $\begin{array}{l}6.6565 \\
4.9978\end{array}$ & $\begin{array}{l}0.0321 * * \\
0.0765^{*}\end{array}$ & $\begin{array}{l}\text { YES } \\
\text { YES }\end{array}$ \\
\hline 16 & $\begin{array}{l}\text { CCA does not Granger cause on PRP } \\
\text { PRP does Granger cause on CCA }\end{array}$ & $\begin{array}{l}5.8756 \\
2.1765 \\
\end{array}$ & $\begin{array}{l}0.0467 * * \\
0.5987\end{array}$ & $\begin{array}{l}\text { YES } \\
\text { NO }\end{array}$ \\
\hline 17 & $\begin{array}{l}\text { CCA does not Granger cause on FP } \\
\text { FP does Granger cause on CCA }\end{array}$ & $\begin{array}{l}6.7981 \\
1.9789 \\
\end{array}$ & $\begin{array}{l}0.0467^{* *} \\
0.3251\end{array}$ & $\begin{array}{l}\text { YES } \\
\text { NO }\end{array}$ \\
\hline
\end{tabular}

Note: where ${ }^{*} \mathrm{p}<0.01$ at $10 \%$ level of significance and ${ }^{* *} \mathrm{p}<0.05$ at $5 \%$ level of significance. ${ }^{* *}$ Granger Causality 


\section{CONCLUSION}

This research also derived and used competitive differentiation advantage \& cost-leadership competitive advantage as business strategies for services and manufacturing sectors and evaluated the impact of product performance, process performance, strategic performance, production performance, and financial performance. The study supported the resource-based view theory and integrated it with the proactive environmental strategies that signify companies' highest level of promise to hold environmental concerns and transform into different firm performance measures. This research concludes that proactive environmental strategy converts into differentiation \& cost-leadership competitive advantages that provide a competitive advantage and long-term growth. The outcomes further exhibited that differentiation \& cost-leadership competitive advantages positively impact the five dimensions of performance measures such as product, process, strategic, production \& financial performances. These five performance measures provide high profitability \& sales revenue, lower energy inputs, natural environmental protection, and a competitive edge over other rival organizations. This research further concluded that technological eco-innovation is the best business strategy, which enhances all performance because technological eco-innovation comprises new technical processes, innovative green products \& services, and protection of the green environment. Hence, the technological ecoinnovation enhances all organizational performances (product, process, strategic, production $\&$ financial) and long-term sustainable development. Similarly, the environmental strategies, differentiation \& cost-leadership advantages provide value chain strategies that also increase the firm's corporate image. The corporate image also improves the image of a firm's products \& services, and customers are more willing to purchase products \& services.

\subsection{Theoretical, practical and societal implications}

The findings of the undertaken study have provided critical theoretical, practical and societal implications for the researchers, industry and society. The companies may incorporate the environment as a cornerstone in short- \& long-term strategies for sustainable development. On the other hand, organizations may provide an eco-friendly environment to society. This research provides the primary foil to the upcoming researchers to carry out their studies using this modified conceptual framework. Moreover, future researchers can also replicate similar research in different industries and regions. Finally, the findings of this research demonstrated the importance of the environment and how companies can perform better by incorporating environmentally friendly business strategies.

\subsection{Limitations and potential areas of future studies}

The undertaken study has particular limitations. For instance, it has taken only a few regional countries. Thus, future studies may be conducted on several developing and emerging countries for more generalizable results. The sample size is not adequate for this research as we have taken several countries. Therefore, future studies could take a more extensive sample for more robust outcomes. We have taken only technological eco-innovation as a mediating variable and corporate image as a moderating variable. However, several other important mediating and moderating factors might be incorporated in future studies for better business strategies. 


\section{References}

1. Ahmed, R. R., Hussain, S., Pahi, M. H., Usas, A., \& Jasinskas, E. (2019). Social Media Handling and Extended Technology Acceptance Model (ETAM): Evidence from SEM-based Multivariate Approach. Transformations in Business \& Economics, 3 (48), 246-271.

2. Ahmed, R. R., Štreimikienè, D., Rolle, J. A., \& Due, P. A. (2020). The COVID-19 Pandemic and the Antecedents for the Impulse Buying Behavior of US Citizens. Journal of Competitiveness, 12 (3), 5-27. https://doi.org/10.7441/joc.2020.03.01

3. Bae, H. S. (2017). The effect of environmental capabilities on environmental strategy and environmental of Korean exporters for green supply chain management. The Asian Journal of Shipping and Logistics, 33 (3), 167-176. https://doi.org/10.1016/j.ajsl.2017.09.006

4. Banerjee, S. B., Iyer, E. S., \& Kashyap, R. K. (2003). Corporate environmentalism: Antecedents and influence of industry type. Journal of Marketing, 67 (2), 106-122. https://doi.org/10.1509/jmkg.67.2.106.18604

5. Barba-Sánchez, V., \& Atienza-Sahuquillo, C. (2016). Environmental proactivity and environmental and economic performance: Evidence from the winery sector. Sustainability, 8 (10), 1014. https://doi.org/10.3390/su8101014

6. Barboza, G. (2019). Endogenous consumers' preferences as drivers of green corporate social responsibility. Social Responsibility Journal, 15 (4), 524-450.

https://doi.org/10.1108/srj-03-2018-0071

7. Becker, S. O., \& Egger, P. H. (2013). Endogenous product versus process innovation. Empirical Economics, 44 (1), 329-354. https://doi.org/10.1007/s00181-009-0322-6

8. Biçakcıoglu, N. (2018). Green business strategies of exporting manufacturing firms: Antecedents, practices, and outcomes. Journal of Global Marketing, 31 (4), 246-269. https://doi.org/10.1080/08911762.2018.1436731

9. Byrne, B. M. (2009). Structural Equation Modeling with AMOS, Basic Concepts, Application and Programming. (2nd ed.). New Jersey: Hillsdale.

10. Chang, C. H. (2016). The Determinants of Green Product Innovation Performance. Corporate Social Responsibility and Environmental Management, 23 (2), 65-76. https://doi.org/10.1002/csr.1361

11. Cheng, C. C., Yang, C. 1., \& Sheu, C. C. (2014). The link between eco-innovation and business performance. Journal of Cleaner Production, 64, 81-90.

https://doi.org/10.1016/j.jclepro.2013.09.050

12. Do, B., \& Nguyen, N. (2020). The Links between Proactive Environmental Strategy, Competitive Advantages and Firm Performance: An Empirical Study in Vietnam. Sustainability, 12 (2), 4962. https://doi.org/10.3390/su12124962

13. Do, B., Nguyen, U., Nguyen, N., \& Johnson, L. W. (2019). Exploring the proactivity levels and drivers of environmental strategies adopted by Vietnamese seafood export processing firms: A qualitative approach. Sustainability, 11 (14), 3964. https://doi.org/10.3390/su11143964

14. Emory, C. W., \& Cooper, D. R. (1991). Business Research Methods (4th ed.). Homewood: Richard D Irwin.

15. Fousteris, A., Didaskalou, E., Tsogas, M. M., \& Georgakellos, D. (2018). The environmental 
strategy of businesses as an option under recession in Greece. Sustainability, 10 (12), 4399. https://doi.org/10.3390/su10124399

16. Ghisetti, C., \& Rennings, K. (2014). Environmental innovations and profitability: How does it pay to be green? An empirical analysis of the German innovation survey. Journal of Cleaner Production, 75, 106-117. https://doi.org/10.1016/j.jclepro.2014.03.097

17. González-Benito, J., \& González-Benito, Ó. (2006). A review of determinant factors of environmental proactivity. Business Strategy and the Environment, 15 (2), 87-102. https://doi.org/10.1002/bse.450

18. Gupta, H., \& Barua, M. K. (2018). A framework to overcome barriers to green innovation in SMEs using BWM and Fuzzy TOPSIS. Science of the Total Environment, 633, 122-139. https://doi.org/10.1016/j.scitotenv.2018.03.173

19. Hair, J. F., Hult, G. T. M., Ringle, C. M., \& Sarstedt, M. (2017). A primer on partial least squares structural equation modeling (PLS-SEM) (2nd ed.). Thousand Oaks, CA: Sage.

20. Han, H., Yu, J., \& Kim, W. (2019). Environmental Corporate Social Responsibility and the Strategy to Boost the Airline's Image and Customer Loyalty Intentions. Journal of Travel \& Tourism Marketing, 36 (3), 371-383. https://doi.org/10.1080/10548408.2018.1557580

21. Hart, S. L., \& Dowell, G. (2011). A natural-resource-based view of the firm: Fifteen years after. Journal of Management, 37 (5), 1464-1479. https://doi.org/10.1177/0149206310390219

22. Hayes, A. F., \& Rockwood, N. J. (2020). Conditional process analysis: Concepts, computation, and advances in modeling of the contingencies of mechanisms. American Behavioral Scientist, 64 (1), 19-54. https://doi.org/10.1177/0002764219859633

23. Henriques, I., \& Sadorsky, P. (1999). The relationship between environmental commitment and managerial perceptions of stakeholder importance. Academy of Management Journal, 42 (1), 87-99. https://doi.org/10.5465/256876

24. Jiang, Y., Xue, X., \& Xue, W. (2018). Proactive corporate environmental responsibility and financial performance: Evidence from Chinese energy enterprises. Sustainability, 10 (4), 964. https://doi.org/10.3390/su10040964

25. Junquera, B., \& Barba-Sánchez, V. (2018). Environmental proactivity and firms’ performance: Mediation effect of competitive advantages in Spanish wineries. Sustainability, 10(7), 2155. https://doi.org/10.3390/su10072155

26. Kaiser, H. F. (1974). An index of factorial simplicity. Psychometrika, 39 (1), 31-36. https://doi.org/10.1007/BF02291575

27. Kaletnik, G., \& Lutkovska, S. (2020). Innovative Environmental Strategy for Sustainable Development. European Journal of Sustainable Development, 9 (2), 89-98. https://doi.org/10.14207/ejsd.2020.v9n2p89

28. Katsikeas, C. S., Leonidou, C. N., \& Zeriti, A. (2016). Eco-friendly product development strategy: Antecedents and contingent effects. Journal of the Academy of Marketing Science, 44 (6), 660-684. https://doi.org/10.1007/s11747-015-0470-5

29. Kliestik, T., Misankova, M., Valaskova, K., \& Svabova, L. (2018). Bankruptcy Prevention: New Effort to Reflect on Legal and Social Changes. Science and Engineering Ethics, 24 (2), 791-803. https://doi.org/10.1007/s11948-017-9912-4 
30. Kliestik, T., Valaskova, K., Nica, E., Kovacova, M., \& Lazaroiu, G. (2020). Advanced methods of earnings management: monotonic trends and change-points under the spotlight in the Visegrad countries. Oeconomia Copernicana, 11 (2), 371-400. https://doi.org/10.24136/oc.2020.016

31. Ko, W. W., \& Liu, G. (2017). Environmental Strategy and Competitive Advantage: The Role of Small and Medium-Sized enterprises' Dynamic Capabilities. Business Strategy and the Environment, 26 (5), 584-596. https://doi.org/10.1002/bse.1938

32. Kuo, F. I., Fang, W. T., \& LePage, B. A. (2021). Proactive environmental strategies in the hotel industry: eco-innovation, green competitive advantage, and green core competence. Journal of Sustainable Tourism, 1-22. https://doi.org/10.1080/09669582.2021.1931254

33. Lee, S. Y., \& Rhee, S. K. (2007). The change in corporate environmental strategies: A longitudinal empirical study. Management Decision, 45 (2), 196-216. https://doi.org/10.1108/00251740710727241

34. Lee, Y. C. (2020). Communicating sustainable development: Effects of stakeholder-centric perceived sustainability. Corporate Social Responsibility and Environmental Management, 27 (4), 1540-1551. https://doi.org/10.1002/csr.1900

35. Leonidou, L. C., Christodoulides, P., Kyrgidou, L. P., \& Palihawadana, D. (2017). Internal drivers and performance consequences of small firm green business strategy: The moderating role of external forces. Journal of Business Ethics, 140 (3), 585-606. https://doi.org/10.1007/s10551-015-2670-9

36. Liu, J., \& Shu, C. (2020). Proactive Environmental Strategy, Corporate Venturing, and Firm Performance. Academy of Management Proceedings, 2020 (1), 19394. https://doi.org/10.5465/ambpp.2020.19394abstract

37. Lu, J., Ren, L., Zhang, C., Rong, D., Ahmed, R. R., \& Streimikis, J. (2020). Modified Carroll's Pyramid of Corporate Social Responsibility to Enhance Organizational Performance of SMEs Industry. Journal of Cleaner Production, 271, 1-18. https://doi.org/10.1016/j.jclepro.2020.122456

38. Mishra, P., \& Yadav, M. (2021). Environmental capabilities, proactive environmental strategy and competitive advantage: A natural-resource-based view of firms operating in India. Journal of Cleaner Production, 291, 125249. https://doi.org/10.1016/j.jclepro.2020.125249

39. Murillo-Luna, J. L., Garcés-Ayerbe, C., \& Rivera-Torres, P. (2011). Barriers to the adoption of proactive environmental strategies. Journal of Cleaner Production, 19 (13), 1417-1425. https://doi.org/10.1016/j.jclepro.2011.05.005

40. Olson, E. G. (2008). Creating an enterprise-level "green" strategy. Journal of Business Strategy, 29 (2), 22-30. https://doi.org/10.1108/02756660810858125

41. Omri, A. (2020). Technological innovation and sustainable development: Does the stage of development matter? Environmental Impact Assessment Review, 83, 106398.

https://doi.org/10.1016/j.eiar.2020.106398

42. Pan, C., Guo, H., Jiang, Y., Wang, H., \& Qi, W. (2020). The double effects of female executives' participation on corporate sustainable competitive advantage through unethical environmental behavior and proactive environmental strategy. Business Strategy and the Environment, 29 (6), 2324-2337. https://doi.org/10.1002/bse.2505 
43. Peters, E., Kliestik, T., Musa, H., \& Durana, P. (2020). Product Decision-Making Information Systems, Real-Time Big Data Analytics, and Deep Learning-enabled Smart Process Planning in Sustainable Industry 4.0. Journal of Self-Governance and Management Economics, 8 (3), 16-22. https://doi.org/10.22381/JSME8320202

44. Tullani, H., Saha, R., \& Dahiya, R. (2018). Green Innovation and Ethical Responsibility. International Journal of Sustainable Entrepreneurship and Corporate Social, 3 (1), 35-52. https://doi.org/10.4018/ijsecsr.2018010103

45. Valaskova, K., Throne, O., Kral, P., \& Michalkova, L. (2020). Deep Learning-enabled Smart Process Planning in Cyber-Physical System-based Manufacturing. Journal of Self-Governance and Management Economics 8 (1), 121-127. https://doi.org/10.22381/JSME8120205

\section{Contact information}

Prof. Rižwan Rabeem Abmed, Ph.D.

Indus University

Faculty of Management Sciences

Department of Business Administration \& Commerce

Pakistan

E-mail: riqwanraheemahmed@gmail.com

ORCID: 0000-0001-5844-5502

Prof. Dalia Streimikiene, Ph.D.

Vilnius university, Kaunas Faculty,

Muitines 8, LT-44280

Lithuania

E-mail:dalia.streimikiene@kenf.vu.lt

ORCID: 0000-0002-3247-9912

Prof. Xiaosong Zheng, PhD (corresponding author)

SILC Business School

Shanghai University

P.R.China

E-mail:xiaosong.z̧heng@shu.edu.cn

ORCID: 0000-0002-6388-3619 